\title{
Hyperiid amphipods around the seamounts and islands off northeastern Brazil
}

\author{
Christiane Sampaio de Souza*, Laura Rodrigues da Conceição, Paulo de Oliveira Mafalda Junior
}

Universidade Federal da Bahia, Instituto de Biologia, Departamento de Zoologia.

(Rua Ademar de Barros s/nº. Laboratório de Plâncton Ondina, CEP: 40210-020 - Salvador, BA, Brazil)

*Corresponding author: chsampaio@ig.com.br

\begin{abstract}
Data collected on large-scale surveys around the seamounts and islands off northeastern Brazil provide information on the hyperiid amphipod populations. Thirty-six species were identified. Most of the species belong to the Infraorder Physocephalata, representing 21 genera and 13 families. Thirteen species (Vibilia australis, $L$. latissimus, L. macrophthalmus, L. schizogeneios, Phronima atlantica, Phrosina semilunata, Primno brevidens, Eupronoe minuta, Oxycephalus clause, Rhabdosoma whitei, Amphithyrus bispinosus, Leptocotis tenuirostris and Tetrathyrus forcipatus) have not previously been recorded in this region. The spatial distribution of the hyperiid amphipods was very patchy. Each area of these amounts and islands off northeastern Brazil has different oceanographic features and can be characterised by a clearly defined group of most abundant species.
\end{abstract}

Descriptors: Zooplankton, Variability, Distribution, Oceanographic Characteristics, Oceanic region.

\section{RESUMo}

Dados coletados em cruzeiro de larga escala em torno dos montes submarinos e ilhas ao largo do Nordeste do Brasil forneceram informações sobre os anfípodes hyperiideos. Foram identificadas 36 espécies, a maioria pertencente à infraordem Physocephala, representando 21 gênerose 13 famílias. Treze espécies, Vibilia australis, L. latissimus, L. macrophthalmus, L. schizogeneios, Phronima atlantica, Phrosina semilunata, Primno brevidens, Eupronoe minuta, Oxycephalus clause, Rhabdosoma whitei, Amphithyrus bispinosus, Leptocotis tenuirostris e Tetrathyrus forcipatus são registros novos para a região Nordeste brasileira. A distribuição espacial dos anfípodes hyperiideos foi altamente irregular. Verificou-se que cada área ao redor dos montes submarinos e ilhas ao longo da área estudada apresentaram diferentes características oceanográficas e puderam ser caracterizadas por um grupo definido de espécies mais abundantes.

Descritores: Zooplâncton, Variabilidade, Distribuição, Características Oceanográficas, Região oceânica. 


\section{INTRODUCTION}

Hyperiid amphipods are significant components of epipelagic and mesopelagic communities. In mesoplankton and macroplankton they are only less in abundance than the copepods, euphausiids, chaetognaths, and gelatinous animals (VINOGRADOV, 2005). They are distributed in the water column from the surface layers to the bathypelagial depths, but most of the 250 currently known species occur within the 0 to $100 \mathrm{~m}$ layer (VINOGRADOV et al., 1996). Due to their relatively weak vertical migrations, most plankton surveys deal with the epipelagic hyperiid fauna in different regions; however, the factors that determine the distributional patterns of this group are not fully understood (LAVANIEGOS; OHMAN, 1999), particularly in tropical latitudes. MONTÚ (1994) reported hyperiid amphipod distributions in the northeast of Brazil and LIMA and VALENTIN (2001) in the southeast. This present study is the first to report on planktonic amphipods and their relation, in the northeast of Brazil, to specific environmental factors

The islands in the Atlantic Ocean off northeastern Brazil include the North Brazilian Chain, the Fernando de Noronha Chain and the Saint Peter and Saint Paul Archipelago. With the exception of that of Saint Peter and Saint Paul, these regions also contain several seamounts, with depths (at the summit) ranging from 20 to $250 \mathrm{~m}$ and displaying a great variety in size and shape. The main oceanic currents influencing these areas are the South Equatorial Current (SEC) and the North Brazil Current (NBC), both flowing at the surface and the Equatorial Undercurrent (EUC) flowing through the subsurface layer (RICHARDSON; MCKEE, 1984; PETERSON; STRAMMA, 1991). Submarine relief (e.g., seamounts and islands) and local currents may influence the hydrological processes.

The effects of mesoscale flow around and over seamounts result in higher primary production and increased abundances of phytoplankton and zooplankton. Seamounts alter the surrounding physical regime, often causing nutrient enrichment by vertical mixing of water masses (DOWER et al., 1992). Topographical features may enhance foraging success by concentrating prey through changes in vertical and horizontal water velocity (HERNÁNDEZ-LEÓN, 1991).

Various types of horizontal and turbulent mixing can result in the aggregation or dispersion of planktonic populations. Some zooplankton have wide distributions that encompass a broad spectrum of environmental conditions, while others are restricted to narrow limits of temperature and salinity, which are known to be the most important parameters affecting the distribution and abundance of plankton (MOUNY; DAUVIN, 2002).

In this study, we have analysed the composition, distribution and abundance of the hyperiid amphipods in relation to the general oceanographic characteristics around the seamounts and islands off northeastern Brazil; an oceanic region that has a different hydrographic regime due to topography-flow interactions on thermohaline structures. The working hypothesis was that the composition and distribution pattern of the hyperiid amphipod species are different in each of the four areas studied according to the hydrographical features analyzed and the increasing biomass and species density in the regions with topographical upwelling.

\section{MATERIAL AND METHODS}

The study area, in the Atlantic Ocean off the northeastern coast of Brazil (between $0^{\circ}$ and $6^{\circ} \mathrm{S}$ ), includes four areas (Figure 1): the St. Peter and St. Paul Archipelago, located at $0^{\circ} 56.2^{\prime} \mathrm{N}$ and $29^{\circ} 20.6^{\prime} \mathrm{W}$; the Fernando de Noronha Chain, located from $3^{\circ}$ to $5^{\circ} \mathrm{S}$ and $32^{\circ}$ to $38^{\circ} \mathrm{W}$; the North Brazilian Chain, located from $1^{\circ}$ to $3^{\circ} \mathrm{S}$ and $37^{\circ}$ to $39^{\circ} \mathrm{W}$ and the oceanic area, located from $0^{\circ}$ to $2^{\circ} \mathrm{S}$ and $30^{\circ}$ to $34^{\circ} \mathrm{W}$.

A total of 60 samples were collected in the study area during expeditions made between January and April 1997 (Figure 1). At each station oblique zooplankton tows were made with a Bongo net with a $50 \mathrm{~cm}$ diameter and $500 \mu \mathrm{m}$ mesh opening, from $200 \mathrm{~m}$ depth to the surface. Plankton samples were fixed in seawater with a solution of $4 \%$ formaldehyde neutralised with sodium tetraborate. The abundance of individuals in each sample was estimated by the volume of water filtered by the net and expressed as individuals per $100 \mathrm{~m}^{3}$. Species identification was based on the morphological descriptions given by BOLTOVSKOY (2005). The horizontal distribution and abundance patterns were determined for each species. All specimens have been deposited in the collection of the Plankton Laboratory, Zoology Department, Federal University of Bahia.

Seawater samples for the analysis of phytoplankton biomass (chlorophyll $a$ ) were collected using Nisken Bottles. Chlorophyll a analysis was carried out spectrophotometrically using methods developed on 


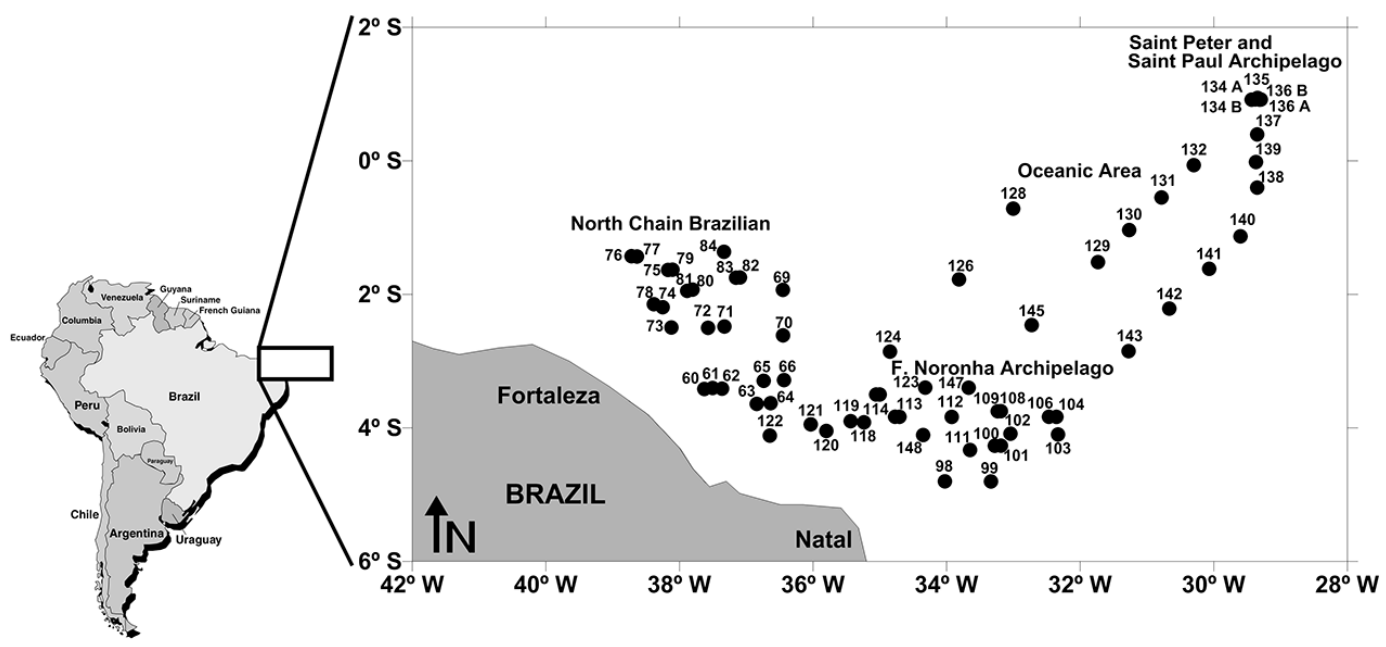

Figure 1. Study area showing the sampling stations around seamounts and islands off northeastern Brazil.

the basis of STRICKLAND and PARSONS (1972). Determination of the zooplankton biomass (organic weight) was carried out according to the methodology of OMORI and IKEDA (1992). Temperature and salinity surfaces were measured using a self-contained Conductivity, Temperature and Depth meter (CTD) (SPE 911 plus).

\section{DATA ANALYSIS}

All variables (temperature $\left(\mathrm{C}^{\mathrm{o}}\right)$ ), salinity, organic weight (g. $\left.100 \mathrm{~m}^{-3}\right)$ and chlorophyll $a\left(\mathrm{mg} \mathrm{L}^{-1}\right)$, were tested for normality using the Kolmogorov and Smirnov test and for homogeneity using the Bartlett test and, when necessary, were transformed accordingly. In order to determine the statistical significance of the spatial variability of biotic and abiotic factors and hyperiid amphipods abundance a Kruskal-Wallis one-way analysis was performed with an alpha value of 0.05 .

Ten species were selected on which to perform multivariate analysis. Thus, the data matrix consisted of 60 stations and 10 species. A similarity matrix was calculated using the Euclidean distance index and cluster analysis was undertaken taking into account sampling units (stations) and species. The cluster dendrogram was cut when the resulting cluster groups were ecologically interpretable; the similarity cut-off levels showed $42 \%$ similarity for the station clusters.

A canonical correspondence analysis (CCA) was performed to determine the existing relationships between abundance of the species and the oceanographic variables (temperature, salinity, chlorophyll $a$ and organic weight).
CCA is a unimodal for non-linear multivariate gradient analysis and was employed using the CANOCO program. The CCA used environmental information to constrain a reciprocal averaging ordination between taxa and the respective sample (TER BRAAK, 1986).

\section{RESULTS}

\section{HYDROGRAPHY, CHLOROPHYLL A AND ZOOPLANK- TON BIOMASS}

Average water temperature at $1 \%$ light penetration was $25.9^{\circ} \mathrm{C}$ (minimum of $21.38^{\circ} \mathrm{C}$ and maximum of $8.96{ }^{\circ} \mathrm{C}$ ). Average salinity at 1\% light penetration was 36.39 PSU, with only small variations (minimum of 35.74 and maximum of 37.03) (Table 1). The horizontal distribution of the salinity showed high values in the North Brazilian Chain and the Fernando de Noronha Chain and lower values in the Saint Peter and Saint Paul Archipelagos.

Salinity profiles down to $150 \mathrm{~m}$ showed a slight increase with depth. These typical distributions were encountered at all stations. The thermocline was present throughout the whole area.

The chlorophyll $a$ fluctuated between 0.19 and $3.03 \mathrm{mg} . \mathrm{L}^{-1}$. In general the lowest values were observed in the North Brazilian Chain and the highest in the oceanic area and Saint Peter and Saint Paul Archipelagos.

The Kruskal-Wallis test $(p<0.01)$ revealed significant differences in temperature, salinity and chlorophyll $a$ as between the four sampling areas.

Zooplankton biomass as calculated from the Bongo catches $(500 \mu \mathrm{m})$ presented lower values oscillating between 0.26 and 4.07 g. $100 \mathrm{~m}^{-3}$ (Figure 2). The distribution 
Table 1. Position and hydrographical data of the stations.

\begin{tabular}{|c|c|c|c|c|c|}
\hline Stations & Longitude (W) & Latitude (S) & Local Depth (m) & Salinity & Temperature $\left({ }^{\circ} \mathrm{C}\right)$ \\
\hline 60 & -38.0067 & -3.4933 & 260 & 36.34 & 27.92 \\
\hline 61 & -37.6383 & -3.4083 & 1057 & 36.76 & 24.25 \\
\hline 62 & -37.5067 & -3.3933 & 258 & 36.98 & 27.1 \\
\hline 63 & -37.3667 & -3.4083 & 250 & 37 & 27.7 \\
\hline 69 & -37.8 & -1.9167 & 53 & 36.2 & 28.08 \\
\hline 70 & -37.9017 & -1.9317 & 1229 & 36.35 & 26.86 \\
\hline 72 & -38.395 & -2.13 & 1045 & 36.58 & 27.09 \\
\hline 74 & -38.7267 & -1.4183 & 800 & 36.6 & 23.67 \\
\hline 75 & -38.635 & -1.4267 & 2341 & 36.68 & 24.7 \\
\hline 76 & -38.1733 & -1.6283 & 210 & 36.22 & 27.73 \\
\hline 77 & -38.1083 & -1.625 & 87 & 36.06 & 28.3 \\
\hline 80 & -37.1567 & -1.7433 & 1500 & 36.18 & 28.09 \\
\hline 81 & -37.1017 & -1.735 & 350 & 36.39 & 25.53 \\
\hline 64 & -36.8517 & -3.635 & 2799 & 36.87 & 27.42 \\
\hline 65 & -36.5217 & -3.6267 & 2979 & 36.77 & 28.72 \\
\hline 66 & -36.4383 & -3.2767 & 3164 & 36.85 & 28.79 \\
\hline 67 & -36.7417 & -3.2883 & 3057 & 36.94 & 24.57 \\
\hline 85 & -35.0583 & -3.4933 & 1119 & 36.61 & 25.64 \\
\hline 86 & -35.0183 & -3.4983 & 1055 & 36.61 & 25.1 \\
\hline 87 & -34.8283 & -3.8217 & 749 & 36.25 & 27.75 \\
\hline 88 & -34.7117 & -3.8267 & 498 & 36.68 & 28.93 \\
\hline 89 & -33.9317 & -3.835 & 1636 & 36.23 & 27.93 \\
\hline 90 & -33.6517 & -3.825 & 393 & 36.21 & 27.84 \\
\hline 93 & -32.4667 & -3.8267 & 1006 & 36.21 & 23.62 \\
\hline 94 & -32.5233 & -3.8317 & 1256 & 36.27 & 25.44 \\
\hline 95 & -33.215 & -4.2583 & 357 & 36.25 & 28.15 \\
\hline 96 & -33.2817 & -4.2633 & 1210 & 36.34 & 23.66 \\
\hline 97 & -33.3383 & -4.7983 & 4419 & 36.45 & 26.98 \\
\hline 98 & -34.0267 & -4.7933 & 3995 & 36.29 & 27.72 \\
\hline 99 & -35.2517 & -3.91 & 1485 & 37 & 27.5 \\
\hline 100 & -35.445 & -3.89 & 2245 & 37.03 & 28.03 \\
\hline 101 & -35.8133 & -4.0317 & 102 & 36.81 & 23.43 \\
\hline 102 & -36.0417 & -3.9367 & 1395 & 36.84 & 27.61 \\
\hline 103 & -36.6567 & -4.11 & 2535 & 36.35 & 28.52 \\
\hline 126 & -33.67 & -3.3883 & 3994 & 36.61 & 24.45 \\
\hline 128 & -34.3167 & -3.39 & 3917 & 36.21 & 27.68 \\
\hline 129 & -34.31 & -4.1017 & 3848 & 36.41 & 27.64 \\
\hline 135 & -29.3517 & 0.8917 & 813 & 35.78 & 23.13 \\
\hline $134 \mathrm{~A}$ & -29.345 & 0.945 & 1334 & 35.82 & 21.38 \\
\hline 113 & -29.43 & 0.9183 & 2294 & 35.72 & 19.94 \\
\hline $134 \mathrm{~B}$ & -29.375 & 0.92 & 1142 & 35.86 & 26 \\
\hline $136 \mathrm{~A}$ & -29.2683 & 0.9383 & 438 & 35.87 & 25 \\
\hline $136 \mathrm{~B}$ & -29.3 & 0.915 & 811 & 35.74 & 22.85 \\
\hline 104 & -31.2767 & -2.845 & 4470 & 35.94 & 22.63 \\
\hline 105 & -30.665 & -2.21 & 1146 & 36.04 & 22.04 \\
\hline 106 & -30.065 & -1.6067 & 4950 & 36.11 & 23.65 \\
\hline 139 & -29.6017 & -1.1233 & 4374 & 36.39 & 22.47 \\
\hline 137 & -29.37 & -0.0233 & 4019 & 36.1 & 23 \\
\hline 115 & -30.2917 & -0.0533 & 4184 & 36.15 & 22.74 \\
\hline 116 & -30.78 & -2.37 & 4248 & 36.28 & 26.12 \\
\hline 117 & -31.265 & -1.0383 & 4211 & 36.44 & 25.11 \\
\hline 118 & -31.7383 & -1.505 & 4753 & 36.37 & 23.13 \\
\hline 119 & -33.0117 & -0.705 & 4558 & 36.58 & 25.87 \\
\hline 120 & -32.2183 & -1.9983 & 4552 & 36.3 & 23.03 \\
\hline 121 & -33.415 & -1.2383 & 4468 & 36.23 & 27.66 \\
\hline 122 & -32.7217 & -2.1183 & 4324 & 36.25 & 25.94 \\
\hline 123 & -33.8133 & -1.7717 & 4354 & 36.23 & 27.69 \\
\hline 124 & -33.2333 & -2.85 & 4105 & 36.29 & 27.18 \\
\hline 125 & -34.2583 & -2.34 & 4120 & 36.29 & 27.28 \\
\hline 127 & -34.815 & -2.8633 & 3870 & 36.2 & 27.99 \\
\hline
\end{tabular}




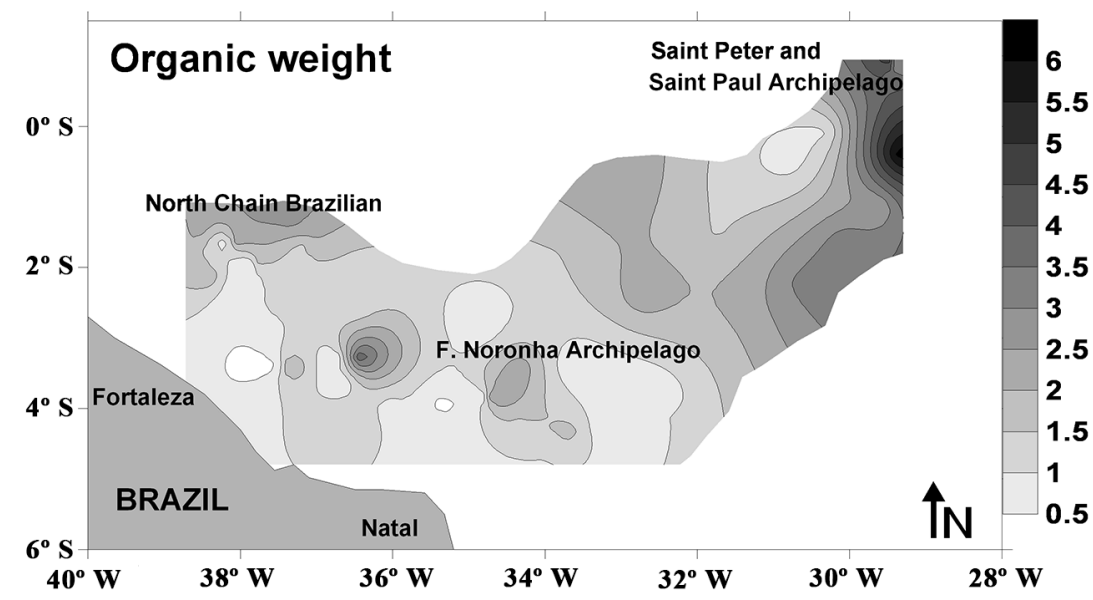

Figure 2. Horizontal distribution of organic weight $\left(\mathrm{g} .100 \mathrm{~m}^{-3}\right)$ around seamounts and islands off northeastern Brazil.

of biomass followed the isotherms very clearly (Figure 2). High biomass values ( $\left.>4 \mathrm{~g} .100 \mathrm{~m}^{-3}\right)$ were found in areas where temperature at $1 \%$ light penetration did not exceed $23.5^{\circ} \mathrm{C}$. At higher water temperatures, such as around the Fernando de Noronha and North Brazilian Chains, biomass ranged between 0.2 and $1.6 \mathrm{~g} .100 \mathrm{~m}^{-3}$. The results showed a decline in zooplankton biomass progressing southward in the study area (from the Saint Peter and Saint Paul Archipelago to the Fernando de Noronha Chain) (Figure 2). According to the Kruskal-Wallis test $(p \leq 0.005)$, the biomass values were significantly different between areas.

\section{SPECIFIC COMPOSITION}

Thirty-six species were identified from the 60 samples around the seamounts and islands within the study area off the northeastern coast of Brazil. Most of the species belong to the Infraorder Physocephalata, representing 21 genera and 13 families (Table 2). Hyperiid amphipod abundances differed significantly across the four sampling regions (Kruskal-Wallis one-way ANOVA, $p \leq 0.001$ ).

Only 10 species were sufficiently abundant as to permit a more detailed discussion of their ecology. The most abundant species was Eupronoe armata, representing $9.58 \%$ of the hyperiid amphipods, followed by Eupronoe maculata (9.22\%), Lestrigonus bengalensis (8.46\%) and Paraphronima gracilis $(7.78 \%)$. The ten most abundant species together accounted for $70 \%$ of total abundance (Figure 3).

\section{SPATIAL DISTRIBUTION}

In this study, the average species density was $81.74 \pm 56.47$ ind $100 \mathrm{~m}^{-3}$; the total density at individual sites ranged between 13.33 and 274.29 ind $100 \mathrm{~m}^{-3}$. The spatial distribution of the hyperiid amphipods shows greater density in the oceanic area close to the Saint Peter and Saint Paul Archipelagos (Figure 4).

The density values of the species ranged from 0.2 to 38.3 ind.100 $\mathrm{m}^{-3}$ (Table 3 (http://www.io.usp.br/index. php/arquivos/send/355-vol-64-no-4-2016/4087-1233tabela-3)). Eupronoe armata, Lestrigonus bengalensis, Anchylomera beossevillei and Tetrathyrus forcipatus were distributed all over the sampling area, being most abundant in the Fernando de Noronha Chain and the North Brazilian Chain and exhibiting lower abundances in the oceanic area (Figure 5).

Eupronoe maculate, Paraphronima gracilis, Hyperietta vosseleri and Lestrigonus latissimus had a wide spatial distribution, being mostly found in the oceanic area and the Saint Peter and Saint Paul Archipelagos, fluctuating between a minimum of $0.92,0.91,0.82$ and 1.15 ind. $100 \mathrm{~m}^{-3}$ and a maximum of $31.91,25.11,21.52$ and 29.89 ind $100 \mathrm{~m}^{-3}$, respectively (Figure 6). Lestrigonus macrophthalnus was found in all areas in low abundances, except for two stations near the Saint Peter and Saint Paul Archipelagos (Figure 7).

\section{RELATIONSHIPS BETWEEN THE SPECIES OF HYPE-} RIID AMPHIPODS AND ENVIRONMENTAL VARIABLES

In the CCA the first two axes were the most important (Table 4). Normally, eigenvalues between 0.3 and 0.5 indicate the good dispersal of species along the respective axes (TER BRAAK, 1986; TER BRAAK; VERDONSCHOT, 1995). This applies to the first axis of the present analyses, thus indicating that it explains the largest proportion of the variance in species composition. 
Table 2. Species list around seamounts and islands off Northeastern Brazil.

\begin{tabular}{|c|c|c|c|c|}
\hline Suborder & Infraorder & Superfamily & Family & Species \\
\hline \multirow[t]{36}{*}{ Hyperiidea } & Physosomata & Scinoidea & Scinidae & Scina curvidactyla Chevreux, 1914 \\
\hline & \multirow[t]{35}{*}{ Physocephalata } & \multirow[t]{5}{*}{ Vibilioidea } & & Vibilia australis Stebbing, 1888 \\
\hline & & & Vibiliidae & V. chuni Behning \& Woltereck, 1912 \\
\hline & & & & V. stebbingi Behning \& Woltereck, 1912 \\
\hline & & & Domonimida & Paraphronima gracilis Claus, 1879 \\
\hline & & & 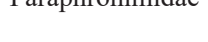 & P. crassipes Claus, 1879 \\
\hline & & \multirow[t]{14}{*}{ Phronimoidea } & & Hyperietta vosseleri (Stebbing, 1904) \\
\hline & & & & Lestrigonus bengalensis Giles, 1887 \\
\hline & & & Hyperiidae & L. latissimus (Bovallius, 1889) \\
\hline & & & & L. macrophthalmus (Vosseler, 1901) \\
\hline & & & & L. schizogeneios (Stebbing, 1888) \\
\hline & & & & Phronima atlantica Guérin-Méneville, 1836 \\
\hline & & & & P. sedentaria (Forsskal, 1775) \\
\hline & & & Phronimidae & P. solitaria Guérin-Méneville, 1844 \\
\hline & & & & P. stebbingi Vosseler, 1901 \\
\hline & & & & Phronimella elongata (Claus) 1862 \\
\hline & & & & Anchylomera blossevillei Milne-Edwards, 1830 \\
\hline & & & Phrocinido & Phrosina semilunata Risso, 1822 \\
\hline & & & 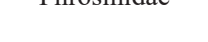 & Primno brevidens Bowman, 1978 \\
\hline & & & & P. macropa Guerin-Meneville, 1836 \\
\hline & & \multirow{16}{*}{$\begin{array}{l}\text { Lycaeopsoidea } \\
\text { Platysceloidea }\end{array}$} & Lycaeopsidae & Lycaeopsis themistoides Claus, 1879 \\
\hline & & & & Eupronoe minuta Claus, 1879 \\
\hline & & & D. . $^{3}$ & E. armata Claus, 1879 \\
\hline & & & 1 Honvilá & E. maculata Claus, 1879 \\
\hline & & & & Sympronoe parva Claus, 1879 \\
\hline & & & Lycaeidae & Simorhynchotus antennarius (Claus, 1871) \\
\hline & & & Brachyscelidae & Brachyscelus crusculum Bate, 1861 \\
\hline & & & & Oxycephalus clausi Bovallius, 1887 \\
\hline & & & & O. piscator Milne-Edwards, 1830 \\
\hline & & & Oronalido & O. armatus Milne-Ewards, 1840 \\
\hline & & & Uayecpirantuac & Rhabdosoma whitei Bate, 1862 \\
\hline & & & & Streetsia porcella (Claus, 1879) \\
\hline & & & & Leptocotis tenuirostris (Claus, 1871) \\
\hline & & & D1 & Amphithyrus bispinosus Claus, 1879 \\
\hline & & & 1 tatysectivat & Tetrathyrus forcipatus Claus, 1879 \\
\hline & & & Parascelidae & Thyropus sphaeroma (Claus) 1879 \\
\hline
\end{tabular}

The eigenvalues were fairly similar for the first and second axes and the correlation between species composition and environmental variables was high (Table 4). Taken together this suggests that the measured environmental variables account for most of the variance in the species data. The four environmental variables explained $39.7 \%$ of the variance in species composition $(0.407 / 1.025$, Table 4).
The dispersion of CCA species scores resulted from linear combinations of the environmental variables. Strong environmental gradients were important correlates with abundance of species in the CCA. Temperature and salinity correlated most strongly with CCA 1. Another suite of environmental variables correlated with CCA 2 and CCA 1, including chlorophyll $a$ and organic weight (Figure 8). Thus, species with low values on CCA 2 and 


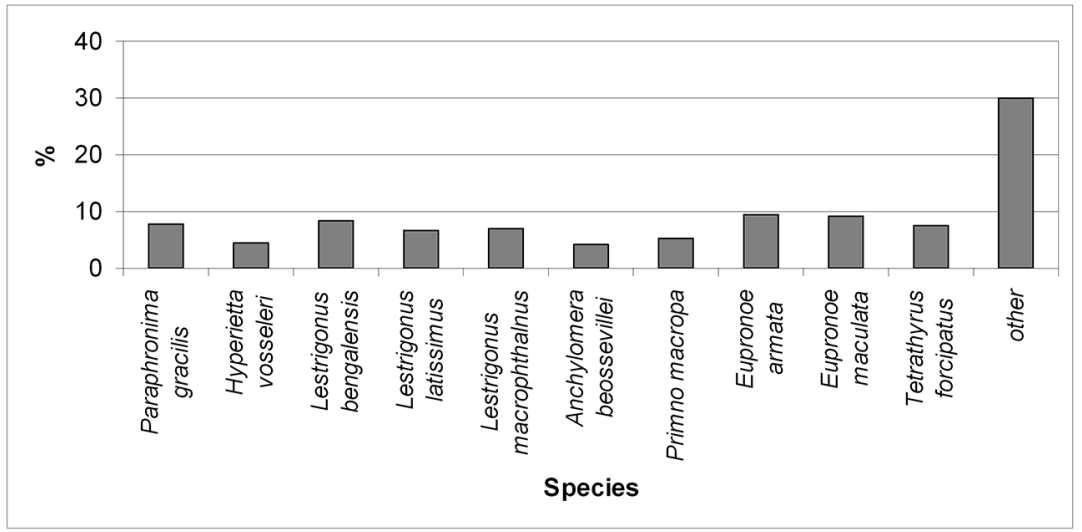

Figure 3. Relative abundance of hyperiid amphipods species around seamounts and islands off northeastern Brazil.

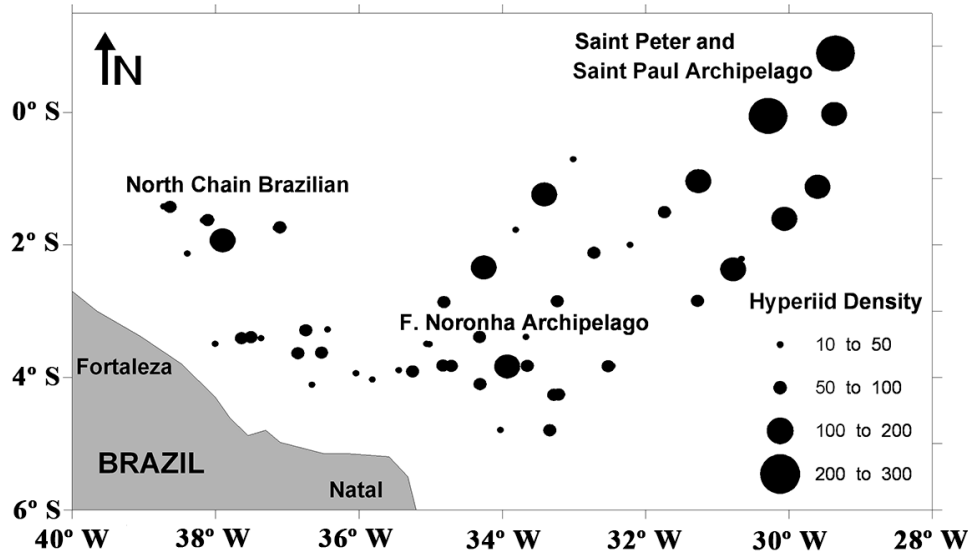

Figure 4. Distribution of total hyperiid density (org. $100 \mathrm{~m}^{-3}$ ) around seamounts and islands off northeastern Brazil.
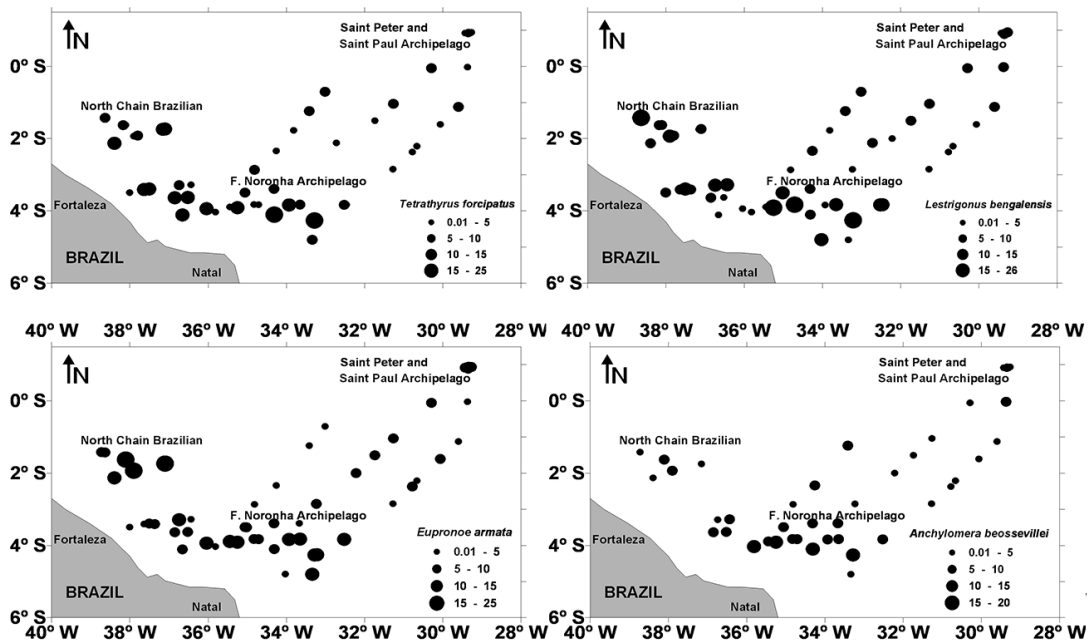

Figure 5. Distribution of Tetrathyrus forcipatus, Lestrigonus bengalensis, Eupronoe armata and Anchylomera bessevillei (org. $100 \mathrm{~m}^{-3}$ ) around seamounts and islands off northeastern Brazil. 


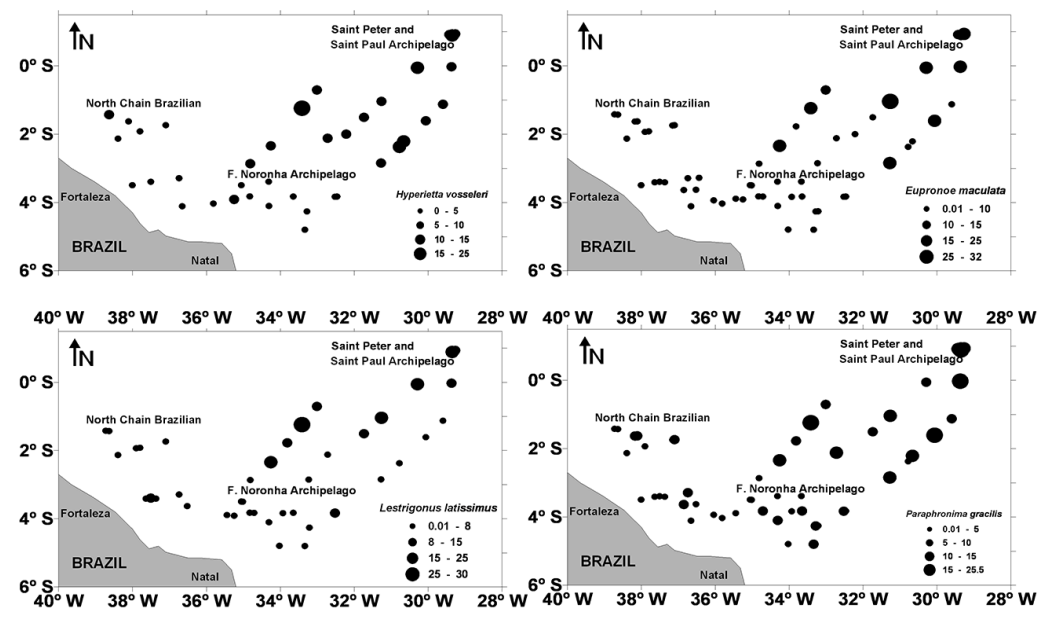

Figure 6. Distribution of Hyperietta vosseleri, Eupronoe maculate, Lestrigonus latissimus and Paraphronima gracilis (org. $100 \mathrm{~m}^{-3}$ ) around seamounts and islands off northeastern Brazil.
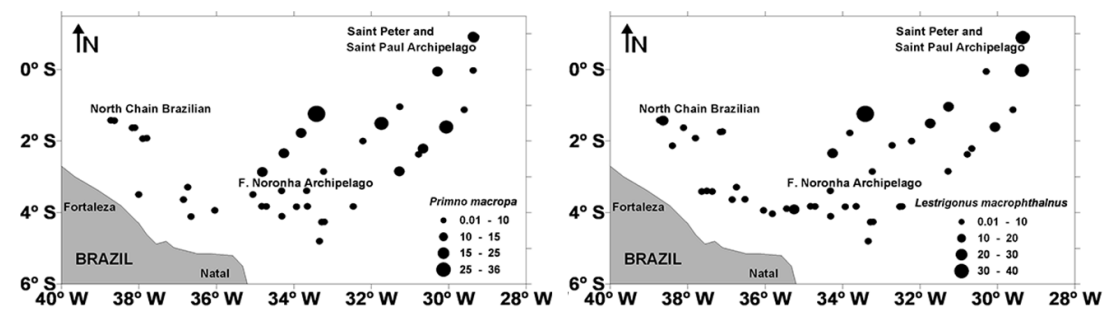

Figure 7. Distribution of Primno macropa and Lestrigonus macrophthalnus (org. $100 \mathrm{~m}^{-3}$ ) around seamounts and islands off northeastern Brazil.

CCA 1 occurred mostly at high salinity and temperature stations, whereas species with high values on CCA 1 and low values on CCA 2 occurred mostly at stations where high chlorophyll $a$ and organic weight were recorded.

To interpret ecological correlations the hyperiid amphipods structure was examined with respect to both CCA axes and their associated environmental relationships. Species with positions near the centre of the ordination (such as Eupronoe maculata) had low correlation with all the environmental variables. The density of the species Lestrigonus bengalensis, Tetrathyrus forcipatus and Anchylomera bessevillei were relatively high at Fernando de Noronha Archipelago where the salinity and temperature were also high. In contrast, the densities of, for instance, Primno macropa, Paraphronima gracilis, Hyperietta vosseleri and Lestrigonus latissimus were high in the oceanic area where temperature and salinity were low. Lestrigonus macrophthalnus has an affinity for waters with lower temperatures where chlorophyll $a$ and organic weight are high (Figure 8).
The cluster analysis showed two groups (Figure 9): one group with $42 \%$ similarity though another group resulted if the cut off level was maintained at $35 \%$ similarity. The station groups are closely linked, corresponding to the species typical of each area, as noted in the CCA.

\section{DISCUSSION}

\section{HYDROGRAPHY, CHLOROPHYLL A AND ZOOPLANKTON BIOMASS}

SOUZA et al. (2013) discuss the hydrographic structure and the distribution of chlorophyll $a$ around seamounts and islands off northeastern Brazil in detail. They present temperature and salinity profiles of single stations as well as temperature and salinity distributions along different transects down to about $400 \mathrm{~m}$ depth.

The stations 137, 139 and 134B, located much closer to the Saint Peter and Saint Paul Archipelagos, were characterised by low temperature and salinity at the surface. SOUZA et al. (2013) studied enrichment processes 
Table 4. Results of Canonical Correspondence Analysis.

\begin{tabular}{lccccc}
\hline Axes & 1 & 2 & 3 & 4 & Total inertia \\
\hline Eigenvalues: & 0.314 & 0.054 & 0.028 & 0.011 & 1.025 \\
Species-environment correlations: & 0.636 & 0.563 & 0.306 & 0.234 & \\
Cumulative percentage variance & & & & 18.6 \\
of species data: & 13.8 & 16.9 & 97.4 & 100 \\
of species-environment relation: & 74.3 & 90.5 & & 1.025 \\
Sum of all eigenvalues & & & & 0.407 \\
Sum of all canonical eigenvalues & & & & \\
\hline
\end{tabular}

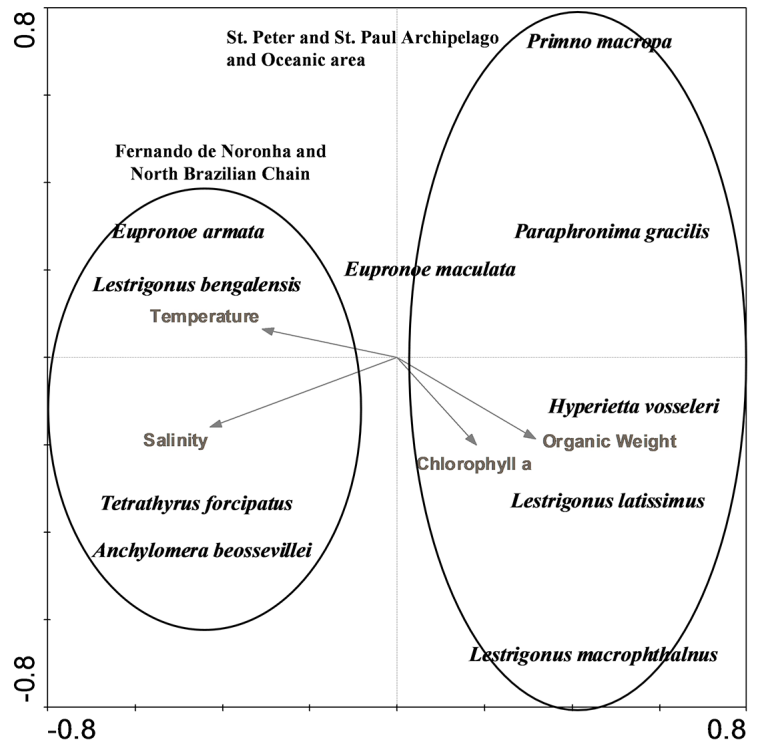

Figure 8. Biplot of the species scores and important environmental correlation vectors in the first two canonical correspondence analysis dimensions.

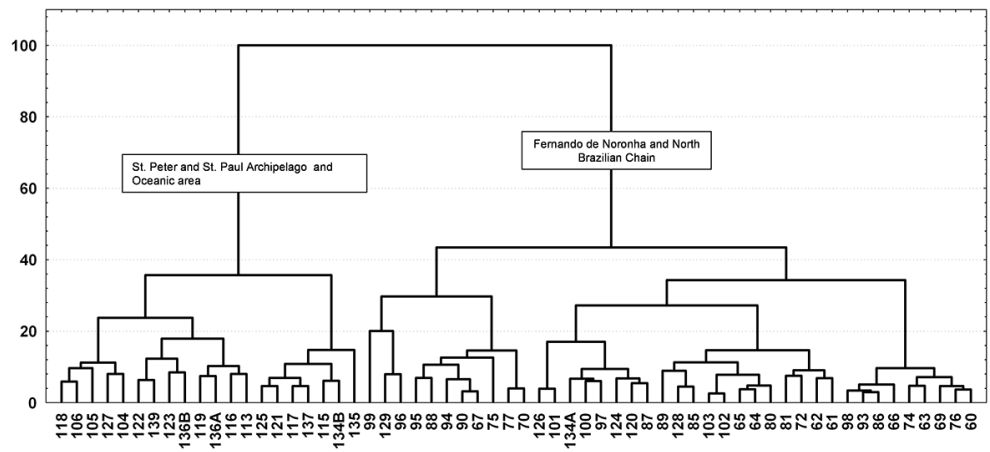

Figure 9. Dendrogram from the analysis of sampling stations using Euclidean distance classification.

originating in deeper waters. They found evidence of upwelling reaching into the mixed layer and into the euphotic zone, with the mixed layer reaching a depth of 50 $\mathrm{m}$. The highest abundances of chlorophyll $a$ coincided with stations where upwelling was recorded by the authors.
Highest biomass values were also found in the oceanic area and closer to the Saint Peter and Saint Paul Archipelagos, coincident with and likely supported by the high concentrations of chlorophyll $a$. These differences were probably produced by the hydrographic conditions, 
which could boost phytoplankton production by injecting greater amounts of nutrients into the euphotic zone.

In general, the biomass of the area studied was very low. BOLTOVSKOY (2005) mentions that maximum zooplankton biomass in the southwestern Atlantic occurs in nerític waters, with values reaching 100 g. $100 \mathrm{~m}^{-3}$ in the top 200 m layer. NEUMANN-LEITÃO (1999) found in coastal and oceanic waters off northeastern Brazil that total biomass of the zooplankton varied from 12.14 mg. $\mathrm{m}^{-3}$ (offshore station) to $117.14 \mathrm{mg} \cdot \mathrm{m}^{-3}$ (inshore station).

Studies carried out in coastal and oceanic Brazilian area show that the western part of the South Atlantic Ocean displays levels of biomass and productivity typical of oligotrophic areas (BRANDINI, 1990; TEXEIRA; GAETA, 1991; METZLER et al., 1997). The low biomass and productivity levels in the Atlantics waters off eastern Brazil are associated with the warm temperature and high salinity surface Tropical Water mass of the Brazil Current (SUSINI-RIBEIRO, 1999).

\section{SPECIFIC COMPOSITION}

The hyperiid species collected in the Atlantic Ocean off Northeast of Brazil in 1997 are widespread in the tropical world ocean, and most of them have been previously recorded in the tropical and subtropical Atlantic Ocean (MONTÚ, 1994; LIMA; VALENTIN, 2001; VINOGRADOV et al., 1996; VINOGRADOV, 1999).

Thirteen species (Vibilia australis, L. latissimus, L. macrophthalmus, L. schizogeneios, Phronima atlantica, Phrosina semilunata, Primno brevidens, Eupronoe minuta, Oxycephalus clause, Rhabdosoma whitei, Amphithyrus bispinosus, Leptocotis tenuirostris and Tetrathyrus forcipatus) had not previously been recorded off northeastern Brazil.

VINOGRADOV (2005) stated that the hyperiid fauna of a certain region could be characterised roughly by the dominant species group. Overall, at least 23 species of hyperiids share the seamounts and islands off the northeast of Brazil with other fauna in the shelf waters (MONTÚ, 1994). The dominant species group off the northeast of Brazil seems to be different from that identified in the south and southeast of Brazil (Lestrigonus bengalensis, Simorhynchotus antennarius and Brachyscelus crusculum) (LIMA; VALENTIN, 2001), although L. bengalensis was among the dominant species. In the Caribbean Sea, this species is less abundant (GASCA; SHIH, 2001; GASCA; SUÁREZ-MORALES, 2004) and in the Sargasso Sea L. bengalensis is not among the 20 most abundant hyperiid species (GASCA, 2007). This species is reported to display a wide range of variation in terms of morphological characteristics (BOWMAN, 1973; VINOGRADOV et al., 1996).

In tropical regions, high concentrations of hyperiids rarely occur. However, even in the tropics their biomass can reach 5 g.m $\mathrm{m}^{-3}$ in isolated swarms of Anchylomera, Phronima or Primno (VINOGRADOV; RUDJAKOV, 1971). BRUSCA (1981) referred to some records of Anchylomera blossevillei off Washington in his revision of the northeast Pacific hyperiids, while Phrosina semilunata was found exclusively in Californian waters. Off Baja California they were associated with oligotrophic waters during the winter of 2005 (LAVANIEGOS; HEREU, 2009).

The diversity of tropical hyperiids is high, although precise data on species compositions and geographic variability are still scarce. This lack of information may result from long-standing poor taxonomy in a number of families (e. g., Hyperiidae, Phronimidae and some others) and the difficulty of assessing faunal distributions based on small standard plankton nets (VINOGRADOV, 2005).

\section{SPATIAL DISTRIBUTION}

The highest hyperiid abundance in the oceanic area close to the Saint Peter and Saint Paul Archipelagos was possibly a consequence of high food availability as high chlorophyll concentrations, as well as highest abundances total zooplankton community, were found in this area. According to SOUZA et al. (2013), these higher concentrations were due to the general hydrographic regime and the weak upwelling caused by the effects of topographical features.

Several studies undertaken in eastern Brazilian waters on the distribution of zooplankton (VANNUCCI, 1957; VALENTIN, 1984) indicated an impact from upwelling on the plankton distribution. GASCA (2003) found that the upwelling was the mesoscale feature that most affected the structure of the hyperiid community in the southern Gulf of Mexico. WILSON et al. (2003) obtained similar results in Australian waters; they attributed the main changes in the macrozooplankton assemblages to the different effects of the upwelling and downwelling. LAVANIEGOS and HEREU (2009) studied Hyperiid amphipods off Baja California and showed that the California Current produces a secondary productive peak during autumn and winter in the oceanic domain, while the main productive peak occurs during spring and summer in coastal waters. 
This means that the bulk of amphipod species are adapted to reproduce at the end of summer and during autumn, thus obtaining the benefits of the offshore productivity. Mesoscale structures such as eddies could be linked to productive areas in the open sea that provide favourable habitats for amphipods (LAVANIEGOS, 2014).

According to ZEIDLER (1978), though Lestrigonus bengalensis is distributed worldwide in tropical waters; it tends to occur in coastal waters, being an epipelagic species. BRINTON et al. (1986) suggested that $L$. bengalensis, the most abundant hyperiid species in the Gulf of California, showed a strong bias towards neritic waters. LIMA and VALENTIN (2001) believed that this species may be a more important component of the inshore plankton than had previously been thought.

GASCA (2004) found that hyperiids were five times more abundant in neritic areas than in the oceanic waters of the Gulf of Mexico. In this survey, overall neritic densities were greater than those in the oceanic zones. $L$. bengalensis dominated in both environments.

Although records of hyperiids in nearshore areas are not uncommon, they are essentially pelagic animals; only Lestrigonus bengalensis tends to inhabit coastal waters (BOWMAN, 1973; VINOGRADOV et al., 1996).

Hyperiid spatial distribution is described as very patchy (THURSTON, 1976; SCHULEMBERGER, 1977). The patchy zooplankton distribution may contribute to the variations found in density records. Low salinity, daytime sampling and low volumes of filtered sea water may also interfere with measured hyperiid densities (LIMA; VALENTIN, 2001). Many hyperiid species are distributed in broad vertical ranges but are more abundant in the upper layer during the night (MACQUART-MOULIN, 1993; VINOGRADOV et al., 1996).

According to LAVAL (1980), the biology and probably part of the distributional patterns of the hyperiids can be closely linked to the dynamics and behavior of the gelatinous zooplankton community (medusae, siphonophores, salpae) with which they are associated. Some hyperiid species, such as Phronima and Phronimella, depend on gelatinous substrates for extended maternal care (AOKI et al., 2013). Other species like Hyperoche mediterrana (HOOGENBOOM; HENNEN, 1985), Vibilia armata and Lestrigonus schizogeneios (LAVAL, 1980) deposit embryos at variable stages of development in a gelatinous host.

In general, each area around the seamounts and islands off northeastern Brazil has different oceanographic features and can be characterised by a defined group of most abundant species.

RELATIONSHIPS BETWEEN THE SPECIES OF HYPERIID AMPHIPODS AND ENVIRONMENTAL VARIABLES

The CCA showed distinctive spatial patterns of dispersion for the various hyperiid amphipod species with respect to the important environmental variables and revealed two main ecological groups formed by the characteristics of the species in each region.

Based on their thermal relationships, hyperiids can be divided into cold-water and warm-water species. Warmwater hyperiid species may also have fairly broad ranges, covering not only tropical but also subtropical areas (VINOGRADOV, 1999). Most warm-water hyperiids are circumtropical. These include representatives of all hyperiid families and practically all genera (except Cyllopus, Hyperiella and probably some abyssal Physosomata). Some families (mainly Oxycephalidae, Platyscelidae, Parascelidae, Lycaeopsidae and Anapronoidae but also Pronoidae, Brachyscelidae, Lycaeidae) are entirely warmwater based (VINOGRADOV, 2005).

In this study Lestrigonus bengalensis, Tetrathyrus forcipatus and Anchylomera bessevillei were associated with high salinity and high temperature, Primno macropa, Paraphronima gracilis, Hyperietta vosseleri and Lestrigonus latissimus showed a close relation to low temperature and low salinity and Lestrigonus macrophthalnus was associated with high chlorophyll $a$ and high organic weight. In the eastern Tropical Pacific, GASCA et al. (2012) found a high dominance of Hyperioides sibaginis and Lestrigonus bengalensis: these species favoured the warm conditions associated with El Niño. However, high tolerance to changes in hydrographic conditions was reported for L. bengalensis in Queensland (ZEIDLER, 1984) and the Taiwan Strait (LIN; CHEN, 1988). For the three dominant amphipod species (C. challengeri, $P$. abyssalis and T. pacifica) in the Oyashio region, the abundance and biomass peaks were in the summer and reproduction occurred during spring and summer (ABE et al., 2016).

Epipelagic species are more susceptible to changes in upper layer temperatures and are good indicators of water advection (LAVANIEGOS, 2014). VALENCIA et al. (2013) found different hyperiid assemblages in the Panama Bight, perhaps modulated by a combination of factors, including: suppressed upwelling, increased temperature and salinity and decreased chlorophyll concentrations. 
Present-day distributions of zooplankton are established over geological time and reflect past dispersal patterns as well as the physiological and ecological requirements of the species. A wide variety of potential responses of different zooplankton taxa may be part of this complex pelagic community (GASCA et al., 2012).

Within the bounds of their geographical regions, zooplanktons exhibit patchy distributions on a wide range of space- and time-scales. Patchiness may result from responses to physical turbulence or mixing, or to chemical gradients, such as salinity changes. Patchiness may also result from interactions between prey and predators, or it may reflect other biological events, such as reproduction (LALLI; PARSONS, 1999)

The functional structure of the pelagic ecosystem is determined by physical, chemical and geological factors and the associated biological responses (PLATT; SATHYENDRANATH, 1999). Our analysis provides evidence that the local hyperiid community structure can be related to the topographical and hydrographical features around seamounts and islands in the waters off the northeastern coast of Brazil.

\section{ACKNOWLEDGEMENTS}

The authors express their thanks to the Ministry of the Environment, Direction of Hydrography and Navigation and ANTARES oceanographical ship, for supporting this study though the REVIZEE program. This study was partly supported by CNPq (Conselho Nacional de Desenvolvimento Cientifico e Tecnológico) as part of the post-doctoral scholarship.

\section{REFERENCES}

ABE, Y.; YAMADA, Y;; SAITO, R.; MATSUNO, K.; YAMAGUCHI, A.; KOMATSU, K.; IMAI, I. Short-term changes in abundance and population structure ofdominant pelagic amphipod species in the Oyashio region during the spring phytoplankton bloom. Reg. Stud. Mar. Sci., v. 3, p. 154-162, 2016.

AOKI, M. N.; MATSUMOTO-OHSHIMA, C.; HIROSE, E.; NISHIKAWA, J. Mother-young cohabitation in Phronimella elongata and Phronima spp. (Amphipoda, Hyperiidea, Phronimidae). J. Mar. Biol. Assoc. UK., v. 93, n. 6, p. 15531556, 2013.

ANTEZANA, T. Plankton of southern Chilean fjords: trends and linkages. Sci. Mar., v. 63, Supl. 1, p. 69-80, 1999.

BOLTOVSKOY, D. Zooplankton of the South Atlantic Ocean. A taxonomic reference work with identification guides and spatial distribution patterns. World Biodiversity Database Compact Disc Series. Expert Center for Taxonomic Identification Bioinformatics, Multimedia Interactive Software. Amsterdam, 2005. DVD ROM.
BOWMAN, T. E. Pelagic amphipods of the genus Hyperia and closely related genera (Hyperiide: Hyperiidae). Smithson. Contrib. Zool., v. 136, p. 1-76, 1973.

BRANDINI, F. P. Hydrography and characteristics of the phytoplankton in shelf and oceanic waters off southeastern Brazil during winter (July/August 1982) and summer (February/March 1984). Hydrobiologia, v. 196, n. 2, p. 111-148, 1990.

BRINTON, E.; FLEMINGER, A.; SIEGEL-CAUSEY, S. The temperate and tropical planktonic biotas of the Gulf of California. Calif. Coop. Ocean. Fish. Invest. Rep., v. 27, p. 228-266, 1986.

BRUSCA, G. J. Annotated keys to the Hyperiidea (Crustacea: Amphipoda) of North American coastal waters. Los Angeles: Allan Hancock Foundation, 1981. 76 p.

DOWE, R. J.; FREELAND, H.; JUNIPER, K. A strong biological response to oceanic flow past Cobb seamount. Deep-Sea Res. A. Oceanogr. Res. Pap., v. 39, n. 7-8, p. 1139-1145, 1992.

GASCA, R.; SHIH, C. T. Hyperiid amphipods of surface waters of the western Caribbean Sea (1991). Crustaceana, v. 74, n. 5, p. 489-499, 2001.

GASCA, R. Hyperiids (Crustacea, Amphipoda) and spring mesoscale features in the Gulf of Mexico. Mar. Ecol., v. 24, n. 4, p. 303-317, 2003.

GASCA, R.; SUÁREZ-MORALES, E. Distribution and abundance of hyperiid amphipods (Crustacea: Peracarida) of the Mexican Caribbean Sea (August 1986). Caribb. J. Sci., v. 40, n. 1, p. 23-30, 2004.

GASCA, R. Distribution and abundance of hyperiid amphipods in relation to summer mesoscale features in the southern Gulf of Mexico. J. Plankton Res., v. 26, n. 9, p. 993-1003, 2004.

GASCA, R. Hyperiid amphipods of the Sargasso Sea. Bull. Mar. Sci., v. 81, n. 1, p. 115-125, 2007.

GASCA, R.; FRANCO-GORDO, C.; GODÍNEZ-DOMÍNGUEZ, E.; SUÁREZ-MORALES, E. Hyperiid amphipod community in the Eastern Tropical Pacific before, during, and after El Niño 1997-1998. Mar. Ecol. Prog. Ser., v. 455, p. 123-139, 2012.

HAMAMÉ, M.; ANTEZANA, T. Chlorophyll and zooplankton in microbasins along the Strait of the Magellan-Beagle Channel passage. Sci. Mar., v. 63, Supl. 1, p. 35-42, 1999.

HERNÁNDEZ-LEÓN, S. Accumulation of mesozooplankton in a wake area as a causative mechanism of the "island-mass effect”. Mar. Biol., v. 109, n. 1, p. 141-147, 1991.

HOOGENBOOM, J.; HENNEN, J. Étude sur les parasites dumacrozooplancton gélatineux dans la rade de Villefranche-sur-Mer (France), avec description des stades de développement de Hyperoche mediterranea Senna (Amphipoda, Hyperiidae). Crustaceana, v. 49, v. 1, p. 233$243,1985$.

LALLI, C. M.; PARSONS, T. R. Biological Oceanography: An introduction. $2^{\text {nd }}$ ed. Burlington: Elsevier ButterworthHeinemann, 1999.

LAVAL, P. Hyperiid amphipods as crustacean parasitoids associated with gelatinous zooplankton. Oceanogr. Mar. Biol. Ann. Rev., v. 18, p. 11-56, 1980.

LAVANIEGOS, B. E.; OHMAN, M. D. Hyperiid amphipods as indicators of climate change in the California Current. In: SCHRAM, F. R.; VON VAUPEL KLEIN, J. C. (Eds.). Crustaceans and the Biodiversity Crisis. Proceedings of the 4th International Crustacean Congress. Amsterdam, 1999. p. 489-509. 
LAVANIEGOS, B. E.; HEREU, C. M. Seasonal variation in hyperiid amphipods and influence of mesoscale structures off Baja California. Mar. Ecol. Prog. Ser., v. 394, p. 137-152, 2009.

LAVANIEGOS, B. E. Pelagic amphipod assemblage associated with subarctic water off the west coast of the Baja California peninsula. J. Mar. Syst., v. 132, p. 1-12, 2014.

LIMA, M. C. G.; VALENTIN, J. L. Preliminary results to the holistic knowledge of the Amphipoda Hyperiidea faunal composition off the Brazilian coast. J. Plankton Res., v. 23, n. 5, p. 469-480, 2001.

LIN, J.; CHEN, R. Distribution of planktonic Amphipoda in western Taiwan Strait. J. Oceanogr. Taiwan Strait., v. 7, n. 4, p. 324-330, 1988 .

MACQUART-MOULIN, C. Répartition verticale, migrations et stratifications superficielles desmysidacés et amphipodes pélagiques sur les marges mediterraneenne et atlantique françaises. J. Plankton Res., v. 15, n. 10, p. 1149-1170, 1993.

MAZZOCCHI, M. G.; IANORA, A. A faunistic study of the copepod assemblages in the Strait of Magellan. Boll. Oceanol. Teor. Appl., v. 9, n. 2-3, p. 163-177, 1991

METZLER, P. M.; GILBERT, P. M.; GAETA, A. S.; LUDLAM, J. M. New and regenerated production in the South Atlantic off Brazil. Deep Sea Res. Part 1. Oceanogr. Res. Pap., v. 44, n. 33, p. 363-384, 1997. Ludlam

MONTÚ, M. Northern Brazilian pelagic amphipods, Suborder Hyperiidea (Crustacea). Nauplius, v. 2, n. 1, p. 131-134, 1994.

MOUNY, P.; DAUVIN, J. C. Environmental control of mesozooplankton community structure in Seine estuary (English Channel). Oceanol. Acta, v. 25, n. 1, p. 13-22, 2002.

NEUMANN-LEITÃO, S.; GUSMÃO, L. M.; SILVA, T. A.; NASCIMENTO-VIEIRA, D. A.; SILVA, A. P. Mesozooplankton biomass and diversity in coastal and oceanic waters off Northeastern Brazil. Arch. Fish. Mar. Res., v. 47, n. 2-3, p. 153-165, 1999.

OMORI, M.; IKEDA, T. Methods in marine zooplankton ecology. Malabar: Krieger Publishing, 1992. 332 p.

PETERSON, R. G.; STRAMMA, L. Upper-level circulation in the South Atlantic Ocean. Prog. Oceanogr., v. 26, n. 1, p. 1-73, 1991

PLATT, T.; SATHYENDRANATH, S. Spatial structure of pelagic ecosystem processes in the global ocean. Ecosystems, v. 2, n. 5, p. 384-394, 1999.

RICHARDSON, P. L.; MCKEE, T. K. Average SeasonalVariation of the Atlantic Equatorial Currents From Historical Ship Drifts. J. Phys. Oceanogr., v. 14, p. 1226-1238, 1984.

SHULENBERGER, E. Hyperiid amphipods from the zooplankton community of the North Pacific central gyre. Mar. Biol., v. 42, n. 4, p. 375-385, 1977.

SOUZA, C. S.; LUZ, J. A. G.; MACEDO, S.; MONTES, M. J. F.; MAFALDA JR, P. O. Chlorophyll $a$ and nutrient distribution around seamounts and islands of the tropical south-western Atlantic. Mar. Freshw. Res., v. 64, n. 2, p. 168-184, 2013.

STRICKLAND, J. D. H.; PARSONS, T. R. A Practical Handbook of Seawater Analyses. 2nd ed. Ottawa: Fisheries Research Board of Canada, 1972.
SUSINI-RIBEIRO, S. M. M. Biomass distribution of pico-, nanoand microplankton on the continental shelf of Abrolhos, East Brazil. Arch. Fish. Mar. Res., v. 47, n. 2-3, p. 271-284, 1999.

TEIXEIRA, C; GAETA, S. A. Contribution of picoplankton to primary production in estuarine, coastal and equatorial waters of Brazil. Hydrobiologia, v. 209, n. 2, p. 117-122, 1991.

TER BRAAK, C. J. F. Canonical correspondence analysis: a new eigenvector technique for multivariate direct gradient analysis. Ecology, v. 67, n. 5, p. 1167-1179, 1986.

TER BRAAK, C. J. F.; VERDONSCHOT, P. F. M. Canonical correspondence analysis and related multivariate methods in aquatic ecology. Aquatic. Sci., v. 57, n. 3, p. 225-289, 1995.

THURSTON, M. H. The vertical distribution and diurnal migration of the Crustacea Amphipoda collected during the SOND cruise, 1965. II. The Hyperiidea and general discussion. J. Mar. Biol. Assoc. UK, v. 56, p. 383-470, 1976.

VALENCIA, B.; LAVANIEGOS, B. E.; GIRALDO, A.; RODRÍGUEZ-RUBIO, E. Temporal and spatial variation of hyperiid amphipod assemblages in response to hydrographic processes in the Panama Bight, eastern tropical Pacific. Deep Sea Res. Part 1. Oceanogr. Res. Pap., v. 73, p. 46-61, 2013.

VALENTIN, J. L. Analyse des paramètres hydrobiologiques dans la remontée de Cabo Frio (Brésil). Mar. Biol., v. 82, n. 3, p. 259-276, 1984.

VANNUCCI, M. On Brazilian hydromedusae and their distribution in relation to different water masses. Bol. Inst. Oceanogr., v. 8, n. 1-2, p. 23-109, 1957.

VINOGRADOV, M. E.; RUDJAKOV, J. A. Diel changes in the vertical distribution of the replaced plankton volumes in the western equatorial Pacific. In: VINOGRADOV, M. E. (Ed.). Functioning of pelagic communities in the tropical regions of the ocean. Moscow: Nauka, 1971. p. 179-188.

VINOGRADOV, M. E.; VOLKOV, A.; SEMENOVA, T. N. Hyperiid Amphipods (Amphipoda, Hyperiidea) of the World Oceans. Washington: Smithsonian Institution Libraries, 1996.

VINOGRADOV, G. Amphipoda. In: BOLTOVSKOY, D. (Ed.). Zooplankton of the Southwestern Atlantic. Leiden: Backhuys Publishers, 1999. p. 1141-1240.

VINOGRADOV, G. Amphipoda. In: BOLTOVSKOY, D. (Ed.). Zooplankton of the South Atlantic Ocean: A taxonomic reference work with identification guides and spatial distribution patterns. World Biodiversity Database Compact Disc Series. Expert Center for Taxonomic Identification. Bioinformatics, Multimedia Interactive Software. Amsterdam, 2005. DVD ROM.

WILSON, S. G., CARLETON, J. H.; MEEKAN, M. G. Spatial and temporal patterns in the distribution and abundance of macrozooplankton on the southern North West Shelf, Western Australia. Estuar. Coast. Shelf Sci., v. 56, n. 5-6, p. 897-908, 2003.

ZEIDLER, W. Hyperiidea (Crustacea: Amphipoda) from Queensland Waters. Aust. J. Zool. Suppl. Ser., v. 59, p. 1-93, 1978.

ZEIDLER, W. Distribution and abundance of some Hyperiidea (Crustacea: Amphipoda) in northern Queensland waters. Aust. J. Mar. Freshw. Res., v. 35, n. 3, p. 285-305, 1984. 
